ISSN: 2302-8556

E-Jurnal Akuntansi Universitas Udayana

Vol.23.3.Juni (2018): 2009-2033

DOI: https://doi.org/10.24843/EJA.2018.v23.i03.p15

\title{
Pengaruh Penekanan Anggaran dan Kapasitas Individu terhadap Senjangan Anggaran pada Organisasi Perangkat Daerah Kabupaten Badung
}

\author{
Ni Made Dwi Maheni ${ }^{1}$ \\ I Made Pande Dwiana Putra ${ }^{2}$
}

${ }^{1}$ Fakultas Ekonomi dan Bisnis Universitas Udayana (Unud), Bali, Indonesia email: dmaheni96@gmail.com/telp: +6287860914446

${ }^{2}$ Fakultas Ekonomi dan Bisnis Universitas Udayana (Unud), Bali, Indonesia

\begin{abstract}
ABSTRAK
Senjangan anggaran merupakan tindakan bawahan yang dengan sengaja memasukkan biaya lebih tinggi dari yang seharusnya dan pendapatan lebih rendah dari yang seharusnya agar anggaran lebih mudah dicapai. Ada beberapa faktor yang dapat mempengaruhi senjangan anggaran. Penelitian ini bertujuan untuk mengetahui pengaruh penekanan anggaran dan kapasitas individu terhadap senjangan anggaran. Penelitian ini dilakukan pada Organisasi Perangkat Daerah Kabupaten Badung. Jumlah sampel yang diambil sebanyak 50 orang, dengan menggunakan metode nonprobability sampling dengan cara purposive sampling. Metode pengumpulan data yang digunakan yaitu kuesioner, wawancara dan dokumentasi. Teknik analisis yang digunakan regresi linier berganda. Berdasarkan hasil analisis ditemukan bahwa penekanan anggaran berpengaruh positif terhadap senjangan anggaran dan kapasitas individu berpengaruh negatif terhadap senjangan anggaran.
\end{abstract}

Kata Kunci : anggaran, penekanan anggaran, kapasitas individu, senjangan anggaran

\begin{abstract}
A budget slack is a subordinate act that deliberately imposes a higher cost than it should and lower revenue than it should for the budget to be more easily achieved. There are several factors that can affect budget slack. This study aims to determine the effect of budgetary pressures and individual capacity on budgetary slack. This research was conducted at the Regional Device Organization of Badung Regency. The number of samples taken as many as 50 people, using nonprobability sampling method by purposive sampling. Data collection methods used were questionnaires, interviews and documentation. Analytical technique used multiple linear regression. Based on the results of the analysis it was found that budgetary pressures had a positive effect on budgetary slack and individual capacity negatively affecting budgetary slack.
\end{abstract}

Keywords: budget, budget emphasis, individual capacity, budget slack 


\section{PENDAHULUAN}

Anthony (2005:73) menyatakan bahwa anggaran adalah sesuatu yang penting sebagai perencanaan dan pengendalian dalam jangka pendek secara efektif dalam organisasi. Anggaran merupakan pernyataan mengenai estimasi kinerja yang hendak dicapai selama periode waktu tertentu yang dinyatakan dalam ukuran finansial, sedangkan penganggaran adalah proses untuk mempersiapkan suatu anggaran (Erina, 2016). Tidak hanya di organisasi sektor swasta, pada organisasi sektor publik termasuk Pemerintah Daerah menggunakan anggaran sebagai pedoman dalam melaksanakan rencana-rencana yang telah disusun oleh pihak-pihak penyusun anggaran. Pada organisasi pemerintah, proses penganggaran harus dapat mengakomodir berbagai usulan-usulan yang telah disampaikan oleh masyarakat sesuai dengan prioritas kebutuhan di daerah. Terkait dengan adanya kepentingan publik didalamnya, anggaran pada organisasi sektor publik harus diinformasikan untuk dapat ditinjau mengenai efektifitas dan efisiensinya. Sedangkan dalam sektor swasta, anggaran merupakan rahasia intern perusahaan yang tertutup untuk publik. Pertanggungjawaban manajemen sektor publik berbeda dengan sektor swasta. Manajemen pada sektor swasta bertanggung jawab kepada pemilik perusahaan (pemegang saham) dan kreditor atas dana yang diberikan. Pada sektor publik manajemen bertanggung jawab kepada masyarakat karena sumber dana yang digunakan oleh organisasi sektor publik dalam rangka pemberian pelayanan publik berasal dari masyarakat. Ozer (2011) menyebutkan melalui anggaran, dapat diketahui 
ISSN: 2302-8556

E-Jurnal Akuntansi Universitas Udayana

Vol.23.3.Juni (2018): 2009-2033

seberapa besar kemampuan pemerintah dalam melaksanakan kegiatan pemerintahan yang menjadi wewenangnya.

Menurut Harahap (2000:89-91), ada tiga metode dalam penyusunan anggaran biasanya di gunakan oleh suatu organisasi, yaitu metode top-down, bottom-up dan gabungan. Penyusunan anggaran pada sektor publik menggunakan metode bottom-up. Metode bottom-up adalah metode penyusunan anggaran yang dilaksanakan dari tingkat bawah ke tingkat yang paling atas atau puncak. Proses penyusunan anggaran yang dilakukan pemerintah disebut dengan Musrenbag (Musyawarah Rencana Pembangunan) yang dilakukan dari Musrenbag tingkat desa hingga tingkat nasional (Erina, 2016). Penyusunan dan penetapan anggaran dilakukan satu tahun sebelum tahun anggaran berkenaan dan pelaksanaan anggaran berlangsung selama satu tahun terhitung mulai awal tahun anggaran baru pada Bulan Januari setiap tahunnya. Dalam pengelolaan keuangan negara atau daerah mencakup penerapan sistem penganggaran berbasis kinerja. Penilaian kinerja berdasarkan tercapai atau tidaknya target anggaran akan mendorong bawahan untuk menciptakan senjangan anggaran.

Penelitian ini mengangkat permasalahan tentang senjangan anggaran pada pemerintah daerah. Senjangan (slack) adalah selisih antara sumber daya yang sebenarnya diperlukan untuk efisien menyelesaikan suatu tugas dan jumlah sumber daya yang lebih besar yang diperuntukkan bagi tugas tersebut (Ikhsan, 2005:176). Fenomena senjangan anggaran pada pemerintah daerah mengindikasikan terjadinya perilaku individu untuk mengupayakan membuat anggaran yang dirasa lebih mudah 
untuk dicapai. Bawahan menciptakan senjangan dengan mengestimasi pendapatan lebih rendah dan mengestimasi biaya yang lebih tinggi. Senjangan anggaran sering terjadi pada tahap perencanaan dan persiapan anggaran daerah, karena penyusunan anggaran didominasi oleh pihak eksekutif dan legislatif, serta kurangnya memperhatikan kesejahteraan masyarakat. Terjadinya senjangan anggaran dalam sektor publik didasari karena adanya asas konservatif atau asas kehati-hatian. Asas konservatif adalah asas perhitungan yang menganut asas maksimal untuk pembiayaan dan minimal untuk pendapatan. Asas konservatif bertujuan untuk menjaga pengeluaran dan penerimaan dalam keadaan seimbang serta menghindari pengeluaran yang berlebihan. Hal tersebut berarti pegawai kurang berani mengambil risiko untuk menargetkan pendapatan yang terlalu tinggi dan pembiayaan yang terlalu rendah.

Penelitian ini dilakukan pada Organisasi Perangkat Daerah Kabupaten Badung. Pemilihan lokasi penelitian ini dikarenakan Kabupaten Badung memiliki kemampuan keuangan tertinggi dibandingkan dengan kabupaten atau kota lainnya di Provinsi Bali yang dapat dilihat pada Tabel 1.1. Semakin tinggi tingkat kemampuan keuangan suatu daerah, maka potensi timbulnya senjangan anggaran juga semakin tinggi (Pradani, 2016). 
ISSN: 2302-8556

E-Jurnal Akuntansi Universitas Udayana

Vol.23.3.Juni (2018): 2009-2033

Tabel 1.

Realisasi Anggaran Pendapatan dan Belanja Daerah (APBD) Kabupaten atau Kota di Bali Tahun 2016 (dalam jutaan rupiah)

\begin{tabular}{ccc}
\hline Kabupaten/Kota & $\begin{array}{c}\text { Pendapatan } \\
\text { Daerah }(\mathbf{R p})\end{array}$ & Belanja Daerah (Rp) \\
\hline Badung & 4.328 .116 & 4.162 .120 \\
Denpasar & 1.943 .173 & 1.871 .441 \\
Buleleng & 2.066 .173 & 2.200 .206 \\
Tabanan & 1.794 .601 & 1.873 .465 \\
Gianyar & 1.682 .779 & 1.786 .418 \\
Karangasem & 1.794 .601 & 1.873 .465 \\
Jembrana & 1.090 .625 & 1.128 .489 \\
Klungkung & 1.062 .218 & 971.294 \\
Bangli & 1.040 .304 & 1.089 .450 \\
\hline
\end{tabular}

Sumber : www.bali.bps.go.id, 2017

Perkembangan realisasi APBD tahun anggaran 2012 - 2016 di Kapubaten Badung dapat dilihat pada Tabel 2 berikut ini.

Tabel 2.

Realisasi Anggaran Pendapatan dan Belanja Daerah (APBD) Kabupaten Badung Tahun Anggaran 2012 - 2016 (dalam jutaan rupiah)

\begin{tabular}{ccccccc}
\hline Tahun & Anggaran & Realisasi & $\begin{array}{c}\text { Persentase } \\
\text { Realisasi }\end{array}$ & Anggaran & Realisasi & $\begin{array}{c}\text { Persentase } \\
\text { Realisasi }\end{array}$ \\
\hline 2012 & 2.410 .694 & 2.620 .854 & 108,72 & 2.671 .643 & 2.334 .080 & 87,36 \\
2013 & 2.718 .030 & 2.954 .663 & 108,71 & 3.027 .776 & 2.755 .460 & 91,01 \\
2014 & 3.155 .737 & 3.459 .986 & 109,64 & 3.614 .007 & 3.276 .164 & 90,65 \\
2015 & 3.627 .735 & 3.735 .130 & 102,96 & 4.051 .572 & 3.446 .634 & 85,07 \\
2016 & 3.948 .077 & 4.328 .116 & 109,63 & 4.628 .106 & 4.162 .120 & 89,93 \\
\hline
\end{tabular}

Sumber : Badan Pengelola Keuangan dan Aset Daerah (BPKAD) Kabupaten Badung, 2017 
Pada Tabel 2. terlihat bahwa setiap tahun, adanya perbedaan antara realisasi dengan target anggaran. Dari data tersebut diduga adanya senjangan anggaran karena terlihat dari setiap tahunnya realisasi anggaran pendapatan daerah lebih tinggi dibandingkan target anggaran pendapatan daerah yang telah ditetapkan, serta realisasi anggaran belanja daerah lebih rendah dibandingkan target anggaran belanja daerah. Sehingga, dari Laporan Realisasi Anggaran tersebut terlihat pemerintah memiliki kinerja yang baik karena mampu melampaui target yang telah ditetapkan sebelumnya.

Anggaran memiliki dampak langsung terhadap perilaku manusia karena proses penyusunan anggaran melibatkan banyak pihak mulai dari pejabat tingkat atas hingga tingkat bawah. Tekanan dari anggaran yang ketat dan kegelisahan atas laporan kinerja yang buruk, sehingga anggaran sering kali dipandang sebagai penghalang kemajuan karier seseorang. Oleh karena itu, adanya penekanan anggaran dan kapasitas individu dapat berpengaruh pada senjangan anggaran.

Penekanan anggaran merupakan variabel yang dapat menimbulkan senjangan anggaran. Penekanan anggaran adalah kondisi bilamana anggaran dijadikan faktor yang paling dominan dalam pengukuran kinerja bawahan pada organisasi (Erni, 2014). Bawahan akan cenderung menciptakan senjangan, jika bawahan meyakini bahwa keberhasilan pencapaian target anggaran akan mendapatkan penghargaan dan kompensasi dari atasannya. Penelitian-penelitian sebelumnya mengungkapkan bahwa penekanan anggaran berpengaruh positif pada senjangan anggaran seperti penelitian yang dilakukan oleh Afiani (2010) dan Erina (2016), dimana penekanan anggaran 
ISSN: 2302-8556

E-Jurnal Akuntansi Universitas Udayana

Vol.23.3.Juni (2018): 2009-2033

yang semakin meningkat akan meningkatkan timbulnya senjangan anggaran dalam penetapan target anggaran. Sebaliknya penelitian yang dilakukan oleh Dunk (1993) dan Sujana (2010) menyatakan penekanan anggaran tidak memiliki pengaruh yang signifikan terhadap senjangan anggaran.

Pada proses penganggaran perlu melibatkan individu yang berkualitas, yaitu memiliki pengetahuan yang cukup untuk mampu mengoptimalkan pengalokasian sumber daya, sehingga mampu meminimalisir terjadinya senjangan anggaran. Kapasitas individu terbentuk dari proses pendidikan, pelatihan maupun pengalaman seseorang. Organisasi birokrasi dalam era otonomi daerah perlu untuk menyiapkan tenaga kerja atau aparatur pemerintah yang mempunyai kemampuan yang baik. Aparatur Pemerintah Daerah diharapkan dapat meningkatkan profesionalitas birokrasi dalam memberikan pelayanan publik. Hal ini sangat penting untuk dilakukan karena dapat mengantisipasi ketidakpastian lingkungan, salah satunya senjangan anggaran (Sandrya, 2013). Penelitian mengenai kapasitas individu masih jarang dilakukan. Salah satu penelitian yang pernah dilakukan yaitu oleh Erina (2016) yang menyatakan kapasitas individu berpengaruh negatif terhadap senjangan anggaran. Sebaliknya penelitian yang dilakukan oleh Basyir (2016) menunjukkan kapasitas individu berpengaruh positif terhadap senjangan anggaran.

Hasil penelitian-penelitian sebelumnya menunjukkan adanya ketidak konsistenan. Berdasarkan fenomena tersebut, penulis terdorong untuk melakukan penelitian mengenai variabel penekanan anggaran dan kapasitas individu terhadap 
potensi terjadinya senjangan anggaran di Organisasi Perangkat Daerah (OPD) Kabupaten Badung. Penelitian dengan menggunakan variabel-variabel tersebut telah banyak diteliti, namun penelitian yang dilakukan penulis dilakukan di tahun ketika terjadinya perubahan jumlah OPD di Pemerintahan Kabupaten Badung yakni tahun 2017. Penelitian mengenai fenomena senjangan anggaran di Pemerintahan Kabupaten Badung pernah dilakukan oleh Pradani pada Tahun 2016. Penelitian tersebut dilakukan di Satuan Kerja Perangkat Daerah (kini bernama Organisasi Perangkat Daerah) Kabupaten Badung yang berjumlah 54 SKPD. Perbedaan jumlah OPD tersebut mengakibatkan perubahan jumlah populasi maupun sampel, yang kemungkinan besar mengubah hasil penelitian pula.

Tujuan dalam penelitian ini adalah untuk mendapatkan bukti empiris tentang pengaruh penekanan anggaran terhadap senjangan anggaran dan pengaruh kapasitas individu terhadap senjangan anggaran. Sedangkan kegunaan dalam penelitian ini adalah secara teoritis penelitian ini diharapkan dapat memperkaya pengetahuan dan wawasan tentang pengaruh penekanan anggaran dan kapasitas individu terhadap senjangan anggaran serta diharapkan hasil penelitian dapat memberikan referensi dalam pengembangan penelitian selanjutnya dengan fenomena yang serupa yang terjadi di Indonesia dan secara praktis Hasil penelitian ini diharapkan dapat memberi kontribusi pemikiran bagi OPD Kabupaten Badung sebagai pertimbangan dalam rangka menurunkan tingkat potensi terjadinya senjangan anggaran dalam proses penyusunan anggaran. 
ISSN: 2302-8556

Dalam kaitannya dengan teori atribusi, penekanan anggaran merupakan faktor eksternal yang dapat mempengaruhi perilaku individu dalam menyusun anggaran. Faktor eksternal dalam teori atribusi yaitu kesulitan-kesulitan yang mungkin dialami dalam mencapai target anggaran. Kesulitan-kesulitan yang ada dalam lingkungan organisasi salah satunya adalah penekanan anggaran.

Penekanan anggaran adalah kondisi bilamana anggaran dijadikan faktor yang paling dominan dalam pengukuran kinerja bawahan pada organisasi. Menurut pandangan teori agensi, kinerja dari organisasi ditentukan berdasarkan usaha dan pengaruh dari kondisi lingkungan. Apabila dalam perusahaan terdapat keadaan dimana anggaran dijadikan satu faktor yang paling dominan dalam mengukur kinerja bawahan, maka bawahan akan cenderung menciptakan senjangan anggaran agar kinerjanya terlihat baik. Hal ini sejalan dengan penelitian yang dilakukan oleh Alfiani (2010), Putra (2014), Purmita (2014) dan Erina (2016) yang membuktikan bahwa penekanan anggaran berpengaruh positif terhadap senjangan anggaran. Berdasarkan penjelasan di atas, hipotesis dalam penelitian ini adalah:

$\mathrm{H}_{1} \quad$ : Penekanan anggaran berpengaruh positif terhadap senjangan anggaran.

Perilaku seseorang yang ikut serta dalam menyusun anggaran akan dipengaruhi oleh kombinasi antara kekuatan internal dan eksternal. Kapasitas individu dalam kaitannya dengan teori atribusi adalah salah satu kekuatan internal yang dapat mempengaruh perilaku individu dalam menyusun anggaran. Kekuatan 
internal adalah kekuatan yang berasal dari dalam diri seseorang berupa kemampuan dan kualitas diri.

Individu yang berkualitas adalah individu yang memiliki pengetahuan cukup yang mampu mengoptimalkan pengalokasian sumber daya sehingga mampu meminimalisir terjadinya senjangan anggaran. Hal tersebut sejalan dengan penelitian yang dilakukan oleh Budi (2009) dan Erina (2016) yang menunjukkan bahwa kapasitas individu berpengaruh negatif terhadap senjangan anggaran. Berdasarkan penjelasan di atas, hipotesis dalam penelitian ini adalah:

$\mathrm{H}_{2}$ : Kapasitas individu berpengaruh negatif terhadap senjangan anggaran.

\section{METODE PENELITIAN}

Penelitian ini menggunakan pendekatan kuantitatif yang berbentuk asosiatif. Pendekatan kuantitatif adalah metode penelitian yang berlandaskan filsafat positivisme, digunakan untuk meneliti populasi dan sampel tertentu yang bertujuan untuk menguji hipotesis yang telah ditetapkan (Sugiyono, 2012:13). Penelitian ini berbentuk asosiatif adalah penelitian yang bertujuan untuk mengetahui hubungan antara dua variabel atau lebih (Sugiyono, 2012:55).

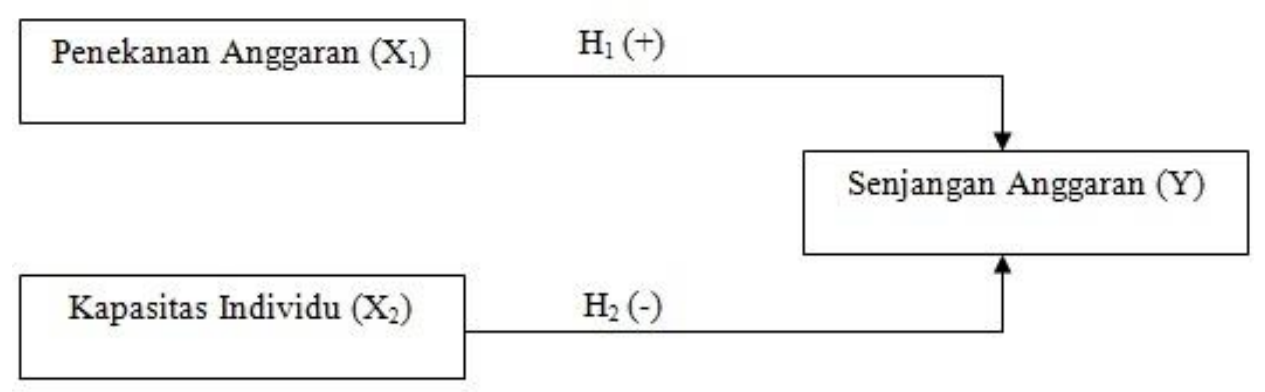

Sumber : Data diolah, 2017 
ISSN: 2302-8556

E-Jurnal Akuntansi Universitas Udayana

Vol.23.3.Juni (2018): 2009-2033

Penelitian ini dilakukan pada 35 OPD (Organisasi Perangkat Daerah) Kabupaten Badung. Obyek penelitian adalah objek atau kegiatan yang mempunyai variasi tertentu yang ditetapkan oleh peneliti untuk dipelajari dan ditarik kesimpulannya (Sugiyono, 2013:13). Obyek penelitian ini adalah senjangan anggaran di OPD Kabupaten Badung Tahun anggaran 2012 - 2016 dengan variabel bebas penekanan anggaran dan kapasitas individu.

Variabel penelitian adalah suatu atribut sifat atau nilai dari orang, obyek atau kegiatan yang mempunyai variasi tertentu yang ditetapkan untuk dipelajari dan ditarik kesimpulannya (Sugiyono, 2013:59). Penelitian ini menggunakan dua jenis variabel yaitu variabel terikat (Y) adalah variabel yang dipengaruhi atau yang menjadi akibat adanya variabel terikat (Sugiyono, 2013:59). Variabel terikat dalam penelitian ini adalah senjangan anggaran (Y) sedangkan Variabel bebas (X) adalah variabel yang mempengaruhi atau yang menjadi sebab perubahannya atau timbulnya variabel terikat (Sugiyono, 2013:59). Variabel bebas dalam penelitian ini adalah penekanan anggaran $\left(\mathrm{X}_{1}\right)$ dan kapasitas individu $\left(\mathrm{X}_{2}\right)$.

Jenis data dalam penelitian ini dapat dibagi menjadi dua jenis yaitu sebagai berikut data kualitatif yaitu data yang dapat dinyatakan dalam bentuk kata, kalimat, skema dan gambar (Sugiyono, 2014:14). Data kualitatif pada penelitian ini adalah pada penelitian ini meliputi data mengenai gambaran umum Kabupaten Badung dan daftar nama OPD Kabupaten Badung dan data kuantitatif adalah data dalam bentuk 
angka yang dapat dinyatakan dan diukur dengan satuan hitung atau data kuantitatif merupakan data kualitatif yang diangkakan (Sugiyono, 2014:13). Data kuantitatif dalam penelitian ini adalah Laporan Realisasi Anggaran Kabupaten Badung tahun anggaran 2012-2016 serta data kualitatif yang dikuantitatifkan dengan bantuan kuesioner yang mengacu pada pengukuran variabel yang digunakan.

Sumber data dalam penelitian ini dibagi menjadi 2 yaitu data primer adalah data yang diperoleh dari sumber data pertama pada objek atau lokasi penelitian (Sugiyono, 2014:193). Data primer dalam penelitian adalah jawaban dari kuesioner yang telah disebar pada seluruh OPD Kabupaten Badung dan Data sekunder adalah data yang tidak langsung memberikan data kepada pengumpul data, misalnya lewat orang lain atau lewat dokumen (Sugiyono, 2014:193) dan data sekunder pada penelitian ini yaitu data mengenai anggaran dan realisasi APBD Kabupaten Badung tahun anggaran 2012 - 2016 dan gambaran umum OPD Kabupaten Badung.

Populasi adalah wilayah generalisasi yang terdiri atas objek atau subjek yang mempunyai kualitas dan karakteristik tertentu yang ditetapkan oleh peneliti untuk dipelajari dan kemudian ditarik kesimpulannya (Sugiyono, 2014:115). Populasi dalam penelitian ini adalah pada 35 OPD di Pemerintah Kabupaten Badung. Sampel adalah bagian dari jumlah dan karakteristik yang dimiliki oleh populasi (Sugiyono, 2013:16). Sampel dalam penelitian ini diambil dari seluruh Kepala OPD, Kepala Sub Bagian Keuangan dan Kepala Sub Bagian Perencanaan. Sampel dalam penelitian ini berjumlah sebanyak 50 orang. Metode pengambilan sampel dalam penelitian ini 
adalah nonprobability sampling dengan cara purposive sampling. Kriteria sampel dalam penelitian ini adalah responden yang telah menjabat minimal lebih dari satu tahun di OPD terkait dan ikut terlibat dalam penyusunan, pelaksanaan dan pertanggungjawaban anggaran.

Metode pengumpulan data yang digunakan dalam penelitian ini adalah sebagai berikut Kuesioner yaitu metode pengumpulan data yang dilakukan dengan cara memberi seperangkat pertanyaan atau pernyataan tertulis kepada responden untuk dijawabnya (Sugiyono, 2012:199). Kuesioner yang disebarkan berupa daftar pertanyaan dan pernyataan tertulis kepada seluruh OPD Kabupaten Badung yaitu sejumlah 35 OPD. Kuesioner yang digunakan dalam penelitian ini yaitu untuk mengukur variabel penekanan anggaran, kapasitas individu dan senjangan anggaran. Dalam penelitian ini, jawaban responden akan diukur dengan menggunakan skala likert. Skala likert digunakan untuk mengukur sikap, pendapat, dan presepsi seseorang atau sekelompok tentang fenomena (Sugiyono, 2014:132).

Adapun kriteria penentuan skor untuk masing-masing pertanyaan atau pernyataan adalah sebagai berikut:

1 : Sangat Tidak Setuju (STS)

2 : Tidak Setuju (TS)

3 : Setuju (S)

4 : Sangat Setuju (SS) 
Wawancara adalah teknik pengumpulan data yang dilakukan apabila peneliti ingin melakukan studi pendahuluan untuk menemukan permasalahan yang harus diteliti, dan juga apabila peneliti ingin mengetahui hal-hal dari responden yang lebih mendalam dan jumlah respondennya sedikit atau kecil (Sugiyono, 2012:411). Wawancara yang dilakukan penulis mengenai proses penyusunan anggaran di OPD Kabupaten Badung. Dokumentasi adalah metode pengumpulan data yang dilakukan dengan cara mempelajari catatan atas peristiwa yang sudah berlalu (Sugiyono, 2012:422). Data yang diperoleh dari proses dokumentasi yaitu data-data mengenai gambaran umum dan Laporan Realisasi Anggaran OPD Kabupaten Badung 2012 2016.

Teknik analisis dalam penelitian ini adalah Analisis regresi linier berganda adalah suatu analisis asosiasi yang digunakan secara bersamaan untuk meneliti pengaruh dua atau lebih variabel bebas terhadap satu variabel tergantung dengan skala interval. Model regresi linear berganda ditunjukkan dalam persamaan sebagai berikut:

$\mathrm{Y}=\alpha+\beta_{1} \mathrm{X}_{1}+\beta_{2} \mathrm{X}_{2}+\varepsilon$

Keterangan:

$\mathrm{Y}=$ Senjangan anggaran

$\mathrm{X}_{1}=$ Penekanan anggaran

$\mathrm{X}_{2}=$ Kapasitas individu

$\alpha=$ Konstanta

$\beta_{1}=$ Koefisien regresi penekanan anggaran

$\beta_{2}=$ Koefisien regresi kapasitas individu

$\varepsilon=$ Standard error 
ISSN: 2302-8556

E-Jurnal Akuntansi Universitas Udayana

Vol.23.3.Juni (2018): 2009-2033

\section{HASIL DAN PEMBAHASAN}

Mendapatkan hasil penelitian yang valid dan reliabel maka harus menggunakan instrumen yang valid dan reliabel. Pengujian instrumen meliputi uji validitas dan reliabilitas. Menurut Sugiyono (2012:109) bahwa suatu instrumen dikatakan valid apabila koefisien korelasi antar butir pertanyaan >0,30. Berdasarkan hasil uji validitas, semua variabel memiliki nilai koefisien korelasi di atas 0,30, sehingga layak dijadikan instrumen penelitian. Hasil uji validitas disajikan pada Tabel 3.

Tabel 3.

Hasil Uji Validitas

\begin{tabular}{cccc}
\hline Variabel & Item & $\begin{array}{c}\text { Pearson's } \\
\text { Correlation }\end{array}$ & Keterangan \\
\hline Senjangan Anggaran $(\mathrm{Y})$ & Y.1 & 0,805 & Valid \\
& Y.2 & 0,824 & Valid \\
& Y.3 & 0,871 & Valid \\
& Y.4 & 0,900 & Valid \\
Penekanan Anggaran $\left(\mathrm{X}_{1}\right)$ & Y.5 & 0,828 & Valid \\
& X1.1 & 0,844 & Valid \\
& X1.2 & 0,898 & Valid \\
& X1.3 & 0,922 & Valid \\
Kapasitas Individu $\left(\mathrm{X}_{2}\right)$ & X1.4 & 0,906 & Valid \\
& X1.5 & 0,930 & Valid \\
& X2.1 & 0,805 & Valid \\
& X2.2 & 0,912 & Valid \\
& X2.3 & 0,883 & Valid \\
& X2.4 & 0,865 & Valid \\
& X2.5 & 0,658 & Valid \\
& X2.6 & 0,874 & Valid \\
\hline
\end{tabular}

Sumber : Data diolah, 2017

Nilai suatu instrumen dikatakan reliabel bila nilai Cronbach's Alpha $>0,70$.

Berdasarkan hasil uji reliabilitas, semua variabel memiliki nilai Cronbach's Alpha di atas 0,70 , sehingga layak dijadikan instrumen penelitian. Secara rinci hasil olah data untuk uji reliabilitas disajikan pada Tabel 4. 
Tabel 4.

Hasil Uji Reliabilitas

\begin{tabular}{lrc}
\hline Variabel & Cronbach's Alpha & Keterangan \\
\hline Senjangan Anggaran $(\mathrm{Y})$ & 0,894 & Reliabel \\
Penekanan anggaran $\left(\mathrm{X}_{1}\right)$ & 0,941 & Reliabel \\
Kapasitas individu $\left(\mathrm{X}_{2}\right)$ & 0,909 & Reliabel \\
\hline Sumber : Data diolah, 2017 & &
\end{tabular}

Berdasarkan Tabel 4 dapat diketahui bahwa seluruh intrumen penelitian adalah reliabel dan layak digunakan untuk mengumpulkan data karena nilai dari Cronbach's Alpha $>0,70$. Cronbach's Alpha $>0,70$ menunjukkan bahwa pengukuran tersebut dapat memberikan hasil yang konsisten apabila dilakukan pengukuran kembali pada waktu yang berbeda pada subyek yang sama.

Statistik deskriptif digunakan untuk memberikan gambaran dari suatu data yang dilihat dari jumlah sampel, nilai minimum, nilai maksimum, nilai rata-rata (mean), dan standar deviasi dari masing-masing variabel di dalam penelitian. Berdasarkan hasil uji statistik deskriptif yang meliputi variabel senjangan anggaran, penekanan anggaran dan kapasitas individu didapat hasil analisis data yang disajikan pada Tabel 5.

Tabel 5.

Hasil Uji Statistik Deskriptif

\begin{tabular}{lrrrr}
\hline \multicolumn{1}{c}{ Variabel } & $\begin{array}{c}\text { Nilai } \\
\text { Minimum }\end{array}$ & $\begin{array}{c}\text { Nilai } \\
\text { Maksimum }\end{array}$ & Rata-rata & Simpangan Baku \\
\hline Senjangan Anggaran $(\mathrm{Y})$ & 1,00 & 3,80 & 2,0720 & 0,80078 \\
Penekanan Anggaran $\left(\mathrm{X}_{1}\right)$ & 1,00 & 3,80 & 2,1000 & 0,89100 \\
Kapasitas Individu $\left(\mathrm{X}_{2}\right)$ & 1,17 & 4,00 & 3,0072 & 0,83868 \\
\hline
\end{tabular}

Sumber : Data diolah, 2017

Berdasarkan Tabel 5 dapat dilihat bahwa jumlah pengamatan $(\mathrm{N})$ dari penelitian ini adalah sebanyak 50. Variabel senjangan anggaran mempunyai nilai 
ISSN: 2302-8556

minimum 1,00 dan nilai maksimum 3,80 sehingga diperoleh skor rata-rata sebesar 2,0720 dan simpangan baku sebesar 0,80078. Variabel penekanan anggaran mempunyai nilai minimum 1,00 dan nilai maksimum 3,80 sehingga diperoleh skor rata-rata sebesar 2,1000 dan simpangan baku sebesar 0,89100. Variabel kapasitas individu mempunyai nilai minimum 1,17 dan nilai maksimum 4,00 sehingga diperoleh skor rata-rata sebesar 3,0072 dan simpangan baku sebesar 0,83868.

Uji normalitas bertujuan untuk mengetahui apakah variabel residualnya memiliki distribusi normal atau tidak (Ghozali, 2013:160). Pengujian ini menggunakan uji statistik non-parametrik Kolmogorov-Smirnov. Seluruh variabel dikatakan berdistribusi normal apabila nilai Asymp Sig (2-tailed) lebih besar dari $\alpha$ (0,05). Hasil uji normalitas disajikan pada Tabel 6.

\section{Tabel 6.} Hasil Uji Normalitas

\begin{tabular}{lcc}
\hline \multicolumn{1}{c}{ Variabel } & $\begin{array}{c}\text { Asymp. Sig } \\
\text { (2-tailed) }\end{array}$ & Keterangan \\
\hline Senjangan Anggaran $(\mathrm{Y})$ & 0,235 & Berdistribusi Normal \\
Penekanan Anggaran $\left(\mathrm{X}_{1}\right)$ & 0,174 & Berdistribusi Normal \\
Kapasitas Individu $\left(\mathrm{X}_{2}\right)$ & 0,112 & Berdistribusi Normal \\
\hline Sumber : Data diolah, 2017 & &
\end{tabular}

Berdasarkan Tabel 6. menunjukkan bahwa variabel $\mathrm{X}$ danY memiliki nilai Asymp Sig (2-tailed) yang lebih besar dari taraf signifikansi 0,05. Hal ini berarti seluruh data berdistribusi normal. Dalam penelitian ini untuk mendeteksi gejala multikolinieritas dilakukan dengan melihat nilai Variance Inflation Factor (VIF). Multikolinearitas dapat dilihat dari nilai VIF, yaitu jika nilai VIF $<10$, berarti tidak 
ada multikolinieritas variabel bebas dalam model regresi ini. Hasil uji multikolinieritas disajikan pada Tabel 7.

Tabel 7. Hasil Uji Multikolinieritas

\begin{tabular}{lrl}
\hline \multicolumn{1}{c}{ Variabel } & VIF & Keterangan \\
\hline Penekanan Anggaran $\left(\mathrm{X}_{1}\right)$ & 1,338 & Bebas Multikolinieritas \\
Kapasitas Individu $\left(\mathrm{X}_{2}\right)$ & 1338 & Bebas Multikolinieritas \\
\hline
\end{tabular}

Sumber : Data diolah, 2017

Berdasarkan Tabel 7. dapat dilihat bahwa seluruh variabel bebas memiliki nilai VIF $<10$. Sehingga, dapat disimpulkan bahwa pada data penelitian ini, tidak terjadi multikolinieritas antara variabel bebas dalam model regresi ini. Dalam penelitian ini, untuk mendeteksi ada atau tidaknya heteroskedastisitas dapat dilakukan dengan melakukan Uji Glejser, yaitu dengan meregres variabel bebas terhadap absolute residual. Jika variabel terikat signifikan mempengaruhi variabel bebas, maka ada indikasi terjadi heterokedastisitas. Hasil uji heteroskedastisitas disajikan pada Tabel 8.

Tabel 8. Hasil Uji Heteroskedastisitas

\begin{tabular}{lrc}
\hline \multicolumn{1}{c}{ Variabel } & Signifikansi & Keterangan \\
\hline Penekanan Anggaran $\left(\mathrm{X}_{1}\right)$ & 0,105 & Bebas Heteroskedastisitas \\
Kapasitas Individu $\left(\mathrm{X}_{2}\right)$ & 0,370 & Bebas Heteroskedastisitas \\
\hline Sumber : Data diolah, 2017 & &
\end{tabular}

Berdasarkan hasil uji heteroskedastisitas pada Tabel 8, terlihat bahwa tidak ada pengaruh variabel bebas $\left(\mathrm{X}_{1}\right.$ dan $\left.\mathrm{X}_{2}\right)$ terhadap absolute residual (abs_res), karena nilai signifikansi lebih besar dari 0,05. Dengan demikian, model yang dibuat tidak mengandung gejala heteroskedastisitas. 
ISSN: 2302-8556

Penelitian ini menganalisis data menggunakan metode analisis regresi berganda. Analisis regresi berganda digu;nakan untuk mengetahui dan menunjukkan arah serta besarnya pengaruh penekanan anggaran, kapasitas individu dan senjangan anggaran. Model analisis ini, yang digunakan sebagai variabel bebas adalah penekanan anggaran $\left(\mathrm{X}_{1}\right)$, kapasitas individu $\left(\mathrm{X}_{2}\right)$. Sedangkan variabel terikat pada penelitian ini adalah senjangan anggaran (Y). Hasil uji analisis regresi linear berganda disajikan pada Tabel 9.

Tabel 9.

Hasil Uji Analisis Regresi Linear Berganda

\begin{tabular}{llrr}
\hline \multicolumn{1}{c}{ Variabel } & \multicolumn{2}{c}{ Koefisien Regresi } & \multicolumn{2}{c}{ Signifikansi } \\
\hline Konstanta & & 2,490 & 0,000 \\
Penekanan Anggaran $\left(\mathrm{X}_{1}\right)$ & & 0,427 & 0,000 \\
Kapasitas Individu $\left(\mathrm{X}_{2}\right)$ & & $-0,437$ & 0,000 \\
\hline F Hitung & $: 44,657$ & & \\
Signifikansi F & $: 0,000$ & & \\
$R$ Square & $: 0,655$ & & \\
Adjusted $R$ Square & $: 0,641 ;$ & &
\end{tabular}

Berdasarkan Tabel 9. dapat dibentuk persamaan regresi linear berganda sebagai berikut.

$\mathrm{Y}=2,490+0,427 \mathrm{X}_{1}-0,437 \mathrm{X}_{2}+\varepsilon$

Persamaan regresi linier berganda diatas dapat diartikan bahwa hasil analisis kelayakan model $\mathrm{F}$ dapat dilihat pada Tabel 9. menunjukkan bahwa nilai $\mathrm{F}$ hitung sebesar 44,567 dengan nilai signifikansi sebesar 0,000 lebih kecil dari 0,05. Hasil ini memberikan arti bahwa variabel penekanan anggaran dan kapasitas individu dapat atau layak digunakan untuk memprediksi variabel senjangan anggaran di Organisasi 
Perangkat Daerah Kabupaten Badung. Koefisien determinasi $\left(\mathrm{R}^{2}\right)$ bertujuan untuk mengukur untuk seberapa jauh kemampuan model dalam menerangkan variasi variabel dependen. Besarnya nilai Adjusted $R^{2}$ adalah seberapa 0,641. Hal ini berarti bahwa $64,1 \%$ variasi besarnya senjangan anggaran dapat dipengaruhi oleh penekanan anggaran dan kapasitas individu. Sedangkan sisanya 35,9\% dipengaruhi oleh variabel-variabel lain di luar model.

Uji hipotesis dilakukan untuk mengetahui apakah ada pengaruh yang signifikan antara variabel bebas terhadap variabel terikat. Level of significance $(\alpha)$ yang digunakan adalah $5 \%(0,05) . \mathrm{H}_{\mathrm{i}}$ diterima jika $p$-value $<\alpha(0,05)$. Berdasarkan Tabel 4.12 hasil pengujian pengaruh masing-masing variabel bebas terhadap variabel terikat dapat dijabarkan sebagai berikut: 1)Nilai t hitung pada variabel penekanan anggaran adalah sebesar 4,800 dengan tingkat signifikansi 0,000. Karena tingkat signifikansi $0,000<\alpha(0,05)$ dan koefisien regresi variabel penekanan anggaran 0,427 $>0$, maka $\mathrm{H}_{1}$ diterima. Hal ini berarti bahwa penekanan anggaran berpengaruh positif terhadap senjangan anggaran. Apabila variabel penekanan anggaran meningkat satu satuan maka akan mengakibatkan peningkatan pula pada variabel senjangan anggaran, dengan asumsi variabel lainnya dianggap konstan. 2) Nilai t hitung pada variabel kapasitas individu adalah sebesar -4,624 dengan tingkat signifikansi 0,000. Karena tingkat signifikansi $0,000<\alpha(0,05)$ dan koefisien regresi yaitu sebesar $-0,437$ $<0$, maka $\mathrm{H}_{2}$ diterima. Hal ini berarti bahwa kapasitas individu berpengaruh negatif terhadap senjangan anggaran. Apabila variabel kapasitas individu meningkat satu 
ISSN: 2302-8556

satuan maka akan mengakibatkan penurunan pada variabel senjangan anggaran, dengan asumsi variabel lainnya dianggap konstan. Hasil penelitian ini menunjukkan bahwa koefisien regresi penekanan anggaran memiliki tanda positif yang artinya $\mathrm{H}_{1}$ diterima. Hal ini berarti apabila tingkat penekanan anggaran meningkat, maka potensi terjadinya senjangan anggaran juga meningkat. Begitu pun sebaliknya, apabila tingkat penekanan anggaran menurun, maka potensi terjadinya senjangan anggaran juga menurun.

Penekanan anggaran merupakan kondisi bilamana dalam suatu perusahaan, anggaran dijadikan alat untuk mengukur kinerja bawahan. Jika realisasi pendapatan kurang dari target anggaran akan diberikan sanksi, sebaliknya jika mampu melebihi target anggaran maka akan diberikan reward. Idealnya, penekanan anggaran memiliki pengaruh signifikan terhadap senjangan anggaran. Dalam kaitannya dengan teori atribusi, penekanan anggaran merupakan faktor eksternal yang dapat mempengaruhi perilaku individu yang menyusun anggaran. Faktor eksternal dalam teori atribusi yaitu kesulitan-kesulitan yang mungkin dihadapi dalam mencapai target anggaran. Kesulitan-kesulitan yang ada dalam lingkungan organisasi salah satunya adalah penekanan anggaran. Apabila dalam perusahaan terdapat keadaan dimana anggaran dijadikan satu faktor yang paling dominan dalam mengukur kinerja bawahan, maka bawahan akan cenderung mencipatakan senjangan anggaran agar kinerjanya terlihat baik. Hasil penelitian sejalan dengan penelitian yang dilakukan oleh Afiani (2010), 
Putra (2014), Purmita (2014) dan Erina (2016) yang menyatakan bahwa penekanan anggaran berpengaruh positif terhadap senjangan anggaran.

Hasil analisis menunjukkan koefisien regresi kapasitas individu memiliki tanda negatif yang artinya $\mathrm{H}_{2}$ diterima. Hal ini menunjukkan bahwa semakin tinggi kapasitas individu yang dimiliki seseorang, maka potensi terjadinya senjangan anggaran semakin rendah. Begitu pun sebaliknya, semakin rendah kapasitas individu yang dimiliki seseorang maka semakin tinggi potensi terjadinya senjangan anggaran.

Teori atribusi, kapasitas individu merupakan salah satu kekuatan internal yang dapat mempengaruhi perilaku individu dalam menyusun anggaran. Kekuatan internal adalah kekuatan yang berasal dari dalam diri seseorang berupa kekuatan yang berasal dari dalam diri seseorang berupa kemampuan dan kualitas diri. Individu yang berkualitas adalah individu yang memiliki pengetahuan. Semakin luas pengetahuan yang dimiki oleh bawahan (agen) tentang anggaran dan realisasinya maka segala informasi yang dimiliki akan disampaikan kepada atasan (prinsipal) untuk mempermudah pencapaian target anggaran yang sesuai dengan tujuan organisasi.

Berdasarkan data yang diperoleh, tingkat pendidikan yang dimiliki responden 52\% di dominasi oleh tingkat pendidikan S1. Menurut Maskun (2008), semakin tinggi tingkat pendidikan, maka semakin positif pandangannya pada senjangan anggaran. Responden yang berpendidikan tinggi dan cenderung memiliki kemampuan untuk bertindak secara rasional dan professional, berani menyatakan pendapat kepada atasan. Selain itu, umur responden $70 \%$ didominasi oleh responden yang memiliki 
ISSN: 2302-8556

umur lebih dari 50 tahun. Umur dapat menunjukkan pengalaman yang dimiliki bawahan dalam proses penyusunan anggaran. Semakin berumur bawahan yang bekerja pada OPD Kabupaten Badung maka semakin lama ia menjabat entah di OPD terkait ataupun di OPD sebelumnya. Terkait dalam proses penganggaran, individu yang memiliki pengetahuan dan pengalaman akan mampu untuk mengalokasikan sumber daya secara optimal, sehingga menghasilkan anggaran yang efektif dan efisien. Dengan demikian, potensi terjadinya senjangan anggaran pun akan semakin kecil. Hasil penelitian ini mendukung hasil penelitian yang dilakukan oleh Budi (2009) dan Erina (2016), menunjukkan bahwa individu yang memiliki kapasitas individu yang optimis, maka dapat menurunkan senjangan anggaran apabila memiliki kesempatan berpartisipasi dalam penyusunan anggaran.

\section{SIMPULAN}

Simpulan yang dapat diambil berdasarkan hasil analisis dan pembahasan dalam penelitian ini adalah Penekanan anggaran berpengaruh postif terhadap senjangan anggaran. Hal ini berarti semakin tinggi tingkat penekanan anggaran pada OPD Kabupaten Badung, maka potensi terjadinya senjangan anggaran meningkat dan Kapasitas individu berpengaruh negatif pada senjangan anggaran. Hal ini berarti semakin tinggi kapasitas individu yang dimiliki oleh pegawai OPD Kabupaten Badung, maka potensi terjadinya senjangan anggaran semakin rendah.

Saran yang dapat disampaikan berdasarkan hasil penelitian adalah pegawai pada OPD Kabupaten Badung sebaiknya tetap mempertahankan kapasitas individu melalui pelatihan-pelatihan yang dapat meningkatkan kemampuan yang dimiliki 
dalam penyusunan anggaran. Peningkatan kemampuan dalam menyusun anggaran dapat menurunkan adanya senjangan anggaran dan penelitian selanjutnya sebaiknya mengambil lokasi yang berbeda, karena kemungkinan hasil penelitian berbeda. Selain itu, penelitian sejenis berikutnya sebaiknya mengunakan variabel independen yang berbeda yang diduga mempunyai pengaruh terhadap terjadinya senjangan anggaran.

\section{REFERENSI}

Anthony dan Govindajaran. 2005. Management Control System. Edisi 11. Buku 2. Penerjemah : Drs. F.X. Kurniawan Tjakrawala, M.Si, Ak. dan Krista, S.E, Ak. Jakarta : Salemba Empat.

Afiani, Dina Nur. 2010. Pengaruh partisipasi Anggaran, Penekanan Anggaran dan Asimetri Informasi terhadap Senjangan Anggaran pada Instansi Pemerintah Daerah (Studi pada Pemerintah Daerah Kabupaten Semarang). Skripsi. Semarang : UNDIP

Basyir, Akhmad Azmi. 2016. Pengaruh Partisipasi Anggaran, Informasi Asimetri, dan Kapasitas Individu terhadap Budgetary Slack pada SKPD Pemerintah Kota Samarinda. AKUNTABEL : Jurnal Ekonomi dan Keuangan, 13(2).

Badan Pengelola Keuangan dan Aset Daerah Pemerintahan Kabupaten Badung. 2017. Laporan Realisasi Anggaran APBD Kabupaten Badung Tahun Anggaran $2012-2016$.

Budi Setiawan. 2009. Pengaruh Kapasitas Individu, Komitmen Organisasi, dan Ketidak Pastian Lingkungan terhadap Budgetary Slack. Skripsi. Fakultas Ekonomi Universitas Atma Jaya Yogyakarta.

Dewik Erina, Ni Putu dan Wayan Suartana. 2016. Pengaruh Partisipasi Penganggaran, Penekanan Anggaran, Kapasitas Individu, dan Kejelasan Sasaran Anggaran pada Senjangan Anggaran. E-Jurnal Akuntansi Universitas Udayana, 15(2): h:973-1000.

Dunk, Alans S. 1993. The Effect of Budget Emphasis and Information Asymmetry on the Relation Between Budgetary Participation and Slack. The Accounting Review. 68: pp: 400-410. 
ISSN: 2302-8556

E-Jurnal Akuntansi Universitas Udayana

Vol.23.3.Juni (2018): 2009-2033

Erni Aprianti, Ni Kadek., I Made Pradana A., dan Edy Sujana. 2014. Pengaruh Partisipasi Anggaran terhadap Senjangan Anggaran dengan Penekanan Anggarandan Komitmen Organisasi sebagai Variabel Moderasi. E-Jurnal Akuntansi Universitas Ganesha 2(1).

Ghozali, Imam. 2013. Aplikasi Analisis Multivariate dengan Program IMB SPSS 21 Update PLS Regresi. Semarang : Badan Penerbit Universitas Diponegoro.

Harahap, Sofyan Safri. 2000. Budgetting-Penganggaran Perencanaan Lengkap Untuk Membantu Manajemen. Cetakan II. Jakarta : Grafindo.

Ikhsan, Arfan dan Ishak, Muhammad. 2005. Akuntansi Keperilakuan. Salemba Empat, Medan.

Ozer, Gokhan \& Emine Yilmaz. 2011. Effects of Procedural Justice Perception, Budgetary Control Effectiveness and Ethical Work Climate on Propensity to Create Budgetary Slack, 2(4): pp: 1-18.

Purmita Dewi, Nyoman dan Adi Erawati, Ni Made. 2014. Pengaruh Partisipasi Penganggaran, Asimetri Informasi, Penekanan Anggaran, dan Komitmen Organisasi pada Senjangan Anggaran. E-Jurnal Akuntansi Universitas Udayana, 9(2): h: 476-486.

Pradani, Komang Kartika Tri dan Ni Made Erawati. 2016. Pengaruh Partisipasi Penganggaran, Job Relevant Information, Kejelasan Sasaran Anggaran, dan Kapasitas Individu pada Senjangan Anggaran. E-Jurnal Akuntansi Universitas Udayana, 17(2): h: 852-884.

Sugiyono. 2014. Metode Penelitian Bisnis. Bandung : Alfabeta.

Sujana, I. K., 2010. Pengaruh Partisipasi Penganggaran, Penekanan Anggaran, Komitmen organisasional, Asimetri Informasi, dan Keti-dakpastian Lingkungan terhadap Budgetary slack. Jurnal Ilmiah Akuntansi dan Bisnis, 5 (2).

Sandrya Dewi, N.L.P. 2013. Analisis Pengaruh Anggaran Partisipatif pada Budgetary Slack dengan Asimetri Informasi, Komitmen Organisasi, Budaya Organisasi, dan Kapasitas Individu sebagai Variabel Moderasi (Studi Kasus pada SKPD di Kabupaten Badung, Bali). Tesis. Denpasar: Universitas Udayana.

Bali dalam Angka. www.bali.bps.go.id. Diakses pada tanggal 18 September 2017. 